\title{
Antibiotics and Allergic Disorders in Childhood
}

\author{
Sue Jordan ${ }^{*}, 1$, Mel Storey ${ }^{2}$ and Gareth Morgan ${ }^{2}$ \\ ${ }^{I}$ School of Health Science, Swansea University, Swansea, SA2 8PP, UK \\ ${ }^{2}$ School of Medicine, Swansea University, Swansea, SA2 8PP, UK
}

\begin{abstract}
Aim: This paper explores the possible association between antibiotics prescribed in infancy and allergic disorders, mainly eczema and asthma, in childhood.

Background: No-one fully understands why childhood asthma and eczema have become so common. Some authorities suggest that there may be an association between eczema and asthma and antibiotics prescribed in childhood; however, others disagree.

Method/Evaluation: The available literature was reviewed to examine the links between prescribed antibiotics and childhood eczema and asthma.

Findings/Key Issue: Some, but not all, research indicates that antibiotic administration in pregnancy, childbirth or infancy may be linked to childhood asthma and eczema, but much uncertainty remains. None of the papers identified stated the doses of antibiotics prescribed. In addition, we were unable to locate studies reporting the interactions between antibiotics and the developing immune system.

Conclusion: Health care professionals should be selective when prescribing antibiotics. Further prospective work is needed to guide the prescribing of antibiotics in childbirth and infancy.
\end{abstract}

Keywords: Allergic disorders, antibiotics, prescribing, adverse drug reactions, evidence based practice.

Health care professionals, particularly nurses, are encouraged to base their practice decisions on research evidence. However, some commentators suggest that this has limitations $[1,2]$. One limitation of the 'evidence-based paradigm' is the absence or paucity, and, consequently, possible bias, of evidence to guide decision-making in some circumstances.

Ideally, every practice activity would be based on the results of randomised, multiple blind, parallel group, placebo controlled pragmatic clinical trials of adequate size, supported by large cohort studies and service users' views. While these standards are sometimes achieved by those investigating the benefits of drugs, there has been no comparable investment in research into the adverse side effects of drugs. As an example, this paper discusses a putative adverse drug reaction of antibiotics: asthma and eczema in childhood.

\section{ALLERGIC DISORDERS IN CHILDHOOD}

Childhood allergic disorders (mainly asthma, eczema and hayfever) are becoming increasingly common and increasingly severe $[3,4]$. Each year, 12 million people in the UK receive treatment for allergic disorders [4]. The prevalence of allergic disorders in childhood increased in the latter half of the twentieth century: by $1995,53.9 \%$ of UK $12-14$ year olds $(n=27,507)$ had experienced asthma, hayfever or

*Address correspondence to this author at the School of Health Sciences, University of Wales, Swansea, Singleton Park, Swansea SA2 8PP, UK; Tel: +44 ( 0) 1792 295789/518541; Fax: 01792 295487;

E-mail: S.E.Jordan@swansea.ac.uk eczema [5], and $41 \%$ of 10 year olds had experienced eczema $(\mathrm{n}=1456)[6]$.

Children with even mild wheezing and asthma lose sleep due to distressing nocturnal symptoms and $1.5 \%$ UK children are kept awake at least 1 night each week by wheezing [4]. Asthma accounts for 128,604 disability adjusted life years in European children aged 0-4, more than any other single condition and more than all malignancies in that age group [7]. The most severely affected children are frequently admitted to hospital, in acute distress, struggling to breathe. If urgent preventative action is not taken, asthma deaths worldwide will increase by $20 \%$ in the next 10 years [8].

Overall, eczema may impose a greater burden on families than type 1 diabetes [9]. Skin conditions account for 9,033 disability adjusted life years in European children aged 0-4 [7]. Children affected by eczema are unable to sleep or concentrate, due to itching: $3 \%$ of UK children are kept awake at least 1 night each week by eczema [4].

The lives of most sufferers are further restricted by their medications. Most children with asthma or eczema receive corticosteroids or immunosuppressants, which can have adverse effects, including increased vulnerability to infections, and further disturbance of body image. The need for rigorous compliance with therapeutic regimens also curtails the child's lifestyle.

The burden of atopic disease is falling disproportionately on children in developed countries, where the prevalence of infectious illness is relatively low [10].

Epidemiological trends, taken with observation studies [11], indicate that modern lifestyles may have disrupted the 
long-standing commensal relationships between humans and their microflora: the hygiene hypothesis $[12,13]$. Children in rural Eastern Europe have, to date, largely escaped the 'allergy epidemic' [14]. However, the culpable environmental components of the modern hygienic environment have not been identified. It has been noticed that the increase in allergic disorders co-incided with the introduction of antibiotics. In the developed world, the prevalence of allergic disorders in childhood may no longer be rising $[15,16]$, whilst, simultaneously, the prescribing of antibiotics in primary care is declining $[17,18]$. When juxtaposed with biologically plausible mechanisms, these contemporaneous trends circumstantially support the association between antibiotics and childhood allergy.

\section{BIOLOGICAL MECHANISMS}

Causal associations between events and disease may be considered with reference to the Bradford Hill criteria [19]: strength, consistency, specificity, timeframe and coherence of association, the dose-response relationship, biological gradient and plausibility, experimental evidence, analogies and precedents. There may be a biological basis for the association between antibiotics in childbirth or infancy and allergic disorders in childhood.

Allergic disorders are associated with atopy [glossary], which occurs when the regulation of the immune system is upset and lymphocytes produce IgE antibodies, rather than IgG antibodies [glossary]. IgE antibodies trigger release of histamine and other inflammatory mediators, which give rise to the signs and symptoms of inflammation. The regulation of the immune system depends on the balance between the 2 main types of T helper cells [glossary]: Th1 and Th2. If the balance deviates towards the Th2 cells, away from those of the Th1 cells, atopy develops. At birth, the Th2 cells predominate. Normally, environmental factors shift the balance of the immune system away from Th2 cells towards Th1 cells, which prevent the development of allergies. However, this change does not occur in children with atopy [20]. This is supported by the observation that children experiencing fever in early life, which stimulates the Th1 cells, are less vulnerable to allergy [21].

In today's hygienic environment, children, and their immune systems, may be under-exposed to certain microorganisms, particularly those that normally inhabit the gut, which have been closely associated with the development of the immune system of the gastro-intestinal tract during evolutionary history. Previous generations of children encountered these microbiological 'old friends' routinely [22]. At birth, the neonate's gastrointestinal tract is rapidly colonised by micro-organisms, mainly from the mother. This colonisation stimulates the lymphoid tissue lining the gut, which contains at least $60 \%$ of the body's lymphocytes, and drives the development of the neonate's immune system [23, 24]. However, the bacteria colonizing the neonatal colon have changed since the 1970s and 1980s, with a decrease in gram negative organisms, such as $E$. coli, and an increase in gram positive microflora, such as staphylococci. Since the 2 groups of micro-organisms affect the gut's immune system in different ways, this may have implications for the development of allergic disorders [25].
Caesarean delivery [26], antibiotics administered to women antenatally [27, 28], or in the peripartum period [29] or to infants [30-32] may change the initial colonisation and the development of the neonatal gut microflora. This could affect the regulation of the immune system, predisposing the child to develop allergic disorders [33]. Consequently, an association between antibiotics, stool flora, the neonatal immune system and the subsequent development of allergy has been postulated [34]. However, the impact of prescribed medications on the Th1/Th2 cytokine [glossary] balance regulating allergy and atopy has not been explored $[35,36]$.

\section{AIM}

This paper explores the possible association between antibiotics in early life and allergic disorders in childhood.

\section{METHODS AND SEARCHES}

To identify the available evidence, Medline was searched during February 2008, using search terms: antibiotics AND childbirth/labour/ parturition AND allergy/ atopy/ eczema/ asthma. Two articles were retrieved, one of which was relevant. The search terms: antibiotics AND eczema/ asthma/ atopy AND adverse drug reactions/ adverse effects, restricted to 'all children' and English language yielded 34, 95 and 31 articles, respectively, of which 9,17 and 8 were relevant data papers, and 23, 64 and 19 were on unrelated topics. Repeating the searches on Embase identified a further 2 relevant articles. When the Cochrane database was searched with the terms antibiotics AND allergy/ allergic disorders/ eczema/ asthma, no relevant reviews were identified. Reference lists were searched for further studies. Most articles retrieved by these terms related to acute responses to antibiotic administration, indicating the relatively low profile of the adverse drug reaction under consideration.

Studies and methods employed were described (Tables 1 and 2). All studies were observational: no experimental work was identified. There is no consensus as to appropriate quality indicators for adverse event research, as discussed below; therefore, we included all papers containing relevant data. The diversity of populations studied and methods employed precluded any statistical analyses.

\section{EXISTING STUDIES}

The largest available dataset indicated that antibiotic administration in the first year of life increased the risk of GP diagnosis of eczema before age 11 . However, there were inconsistencies in the dose-response relationship: one course of antibiotics increased the risk of eczema (adjusted hazard ratio (aHR) 1.22 (95\% CI 1.12-1.34), but four or more did not [37]. Also, this study did not account for antibiotic doses, home environment, family history and laboratory parameters. Farooqi and Hopkin (1998) reported a similar association with antibiotic use in the first 2 years of life [38]. Most retrospective studies have indicated an increased risk of childhood eczema if antibiotics are administered within the first 1-3 years of life [34, 38-43]. Others have found an association with antibiotics in pregnancy, but not in the first year of life [44], while another medical record study [45], a casecontrol study with no figures [46] and a prospective cohort [47] found no association (Table 1). 
Table 1. Antibiotic Exposure and Risk of Eczema in Childhood

\begin{tabular}{|c|c|c|c|c|c|c|c|c|c|}
\hline Ref. & Population & $\begin{array}{c}\text { Time of Antibi- } \\
\text { otic Prescrip- } \\
\text { tion(s) }\end{array}$ & Method & $\begin{array}{l}\text { Antibiotic Use } \\
\text { Assessed by }\end{array}$ & $\begin{array}{l}\text { Number } \\
\text { in Study }\end{array}$ & $\begin{array}{l}\text { Findings } \\
\text { / OR }\end{array}$ & $\begin{array}{l}\text { Linked to } \\
\text { Eczema }\end{array}$ & $95 \% \mathrm{CI}$ & Comments \\
\hline $\begin{array}{l}\text { McKeever et al. } \\
2002 \text { [27] }\end{array}$ & $\begin{array}{l}\text { Children in the } \\
\text { English midlands, } \\
\text { under } 11 \text { years }\end{array}$ & $1^{\text {st }}$ year of life & $\begin{array}{l}\text { Retrospective } \\
\text { cohort. }\end{array}$ & GP records & $\begin{array}{l}21,129, \\
72.3 \% \text { of } \\
\text { available } \\
\text { records }\end{array}$ & (aHR) 1.22 & Yes & $1.12-1.34$ & $\begin{array}{l}\text { Inconsistent } \\
\text { dose-response } \\
\text { relationship. } \\
\text { No data on } \\
\text { confounding } \\
\text { variables }\end{array}$ \\
\hline $\begin{array}{l}\text { Von Mutius } \\
\text { et al. } 1999 \text { [40] }\end{array}$ & $\begin{array}{l}\text { Dresden, children, } \\
\text { aged 5-11 }\end{array}$ & $\begin{array}{l}1^{\text {st }} \text { year } 1-2 \\
\text { courses }\end{array}$ & $\begin{array}{l}\text { Survey, clinical } \\
\text { examination, } \\
\text { venous bloods } \\
\text { for IgE antibod- } \\
\text { ies }\end{array}$ & $\begin{array}{c}\text { Retrospective } \\
\text { questionnaires to } \\
\text { parents }\end{array}$ & 12601 & 1.26 & Yes & $1.05-1.52$ & \\
\hline $\begin{array}{l}\text { Floistrup et al. } \\
2006[34]\end{array}$ & $\begin{array}{c}\text { Steiner school } \\
\text { children and a } \\
\text { comparator group, } \\
\text { age } 5-13\end{array}$ & $1^{\text {st }}$ year & $\begin{array}{l}\text { Survey ques- } \\
\text { tionnaires to } \\
\text { parents } \\
\text { Blood samples } \\
\text { for IgE estima- } \\
\text { tion }\end{array}$ & $\begin{array}{c}\text { Retrospective } \\
\text { questionnaires to } \\
\text { parents. }\end{array}$ & 6733 & 1.61 & Yes & $1.21-2.15$ & \\
\hline $\begin{array}{l}\text { Cohet et al. } 2005 \\
\text { [39] }\end{array}$ & $\begin{array}{c}\text { New Zealand chil- } \\
\text { dren age } 6-7,1584 \\
\text { with previous } \\
\text { notifiable infection } \\
\text { plus a general } \\
\text { population group }\end{array}$ & $1^{\text {st }}$ year & $\begin{array}{l}\text { Survey. } \\
\text { Questionnaires } \\
\text { mailed to par- } \\
\text { ents }\end{array}$ & $\begin{array}{c}\text { Retrospective } \\
\text { questionnaires to } \\
\text { parents. }\end{array}$ & 4123 & 1.40 & Yes & $1.21-1.62$ & $\begin{array}{c}\text { Eczema not } \\
\text { linked to infec- } \\
\text { tions }\end{array}$ \\
\hline $\begin{array}{l}\text { Kummeling } \\
\text { et al. } 2007 \text { [47] }\end{array}$ & $\begin{array}{l}\text { Netherlands, chil- } \\
\text { dren up to } 2 \text { years }\end{array}$ & $\begin{array}{c}1^{\text {st }} 6 \text { months, } \\
\text { including ad- } \\
\text { ministration to } \\
\text { breastfeeding } \\
\text { mothers }\end{array}$ & $\begin{array}{l}\text { Prospective } \\
\text { cohort }\end{array}$ & $\begin{array}{c}\text { Retrospective } \\
\text { questionnaires to } \\
\text { parents. }\end{array}$ & 2764 & 0.94 & No & $0.75-1.18$ & \\
\hline $\begin{array}{c}\text { Faroogqi and } \\
\text { Hopkin } 1998 \\
{[38]}\end{array}$ & $\begin{array}{l}\text { Children up to } 12 \\
\text { years in a family } \\
\text { doctor practice in } \\
\text { Oxfordshire, UK }\end{array}$ & $1^{\text {st }} 2$ years & $\begin{array}{c}\text { Retrospective } \\
\text { cohort using. GP } \\
\text { \& public health } \\
\text { records }\end{array}$ & GP records & 1934 & 2.04 & Yes & $1.53-2.72$ & $\begin{array}{l}\text { Stronger asso- } \\
\text { ciation with } \\
\text { broad spectrum } \\
\text { antibiotic }\end{array}$ \\
\hline $\begin{array}{l}\text { Droste et al. } \\
2000[41]\end{array}$ & $\begin{array}{l}\text { Belgium, children } \\
\text { age } 7-8 \text { years }\end{array}$ & $1^{\text {st }}$ year & $\begin{array}{l}\text { Survey ques- } \\
\text { tionnaires to } \\
\text { parents. Skin } \\
\text { prick tests }\end{array}$ & $\begin{array}{c}\text { Retrospective } \\
\text { questionnaires to } \\
\text { parents. }\end{array}$ & 1206 & 1.3 & $\begin{array}{c}95 \% \mathrm{CI} \\
\text { includes } 1, \\
\text { uncertain }\end{array}$ & $1.0-1.80$ & \\
\hline $\begin{array}{l}\text { Sariachvili et al. } \\
\quad 2007 \text { [44] }\end{array}$ & $\begin{array}{l}\text { Belgium. Infants } \\
\text { age } 1 \text { year }\end{array}$ & $1^{\text {st }}$ year & $\begin{array}{l}\text { Prospective } \\
\text { cohort. Parents' } \\
\text { reports of ec- } \\
\text { zema and IgE } \\
\text { antibody meas- } \\
\text { urements }\end{array}$ & $\begin{array}{c}\text { Retrospective } \\
\text { reports of moth- } \\
\text { ers at } 3,6 \text { and } 12 \\
\text { months }\end{array}$ & 976 & 1.1 & no & $0.8-1.5$ & \\
\hline $\begin{array}{l}\text { Celedon et al. } \\
2002[52]\end{array}$ & $\begin{array}{c}\text { Boston USA, at age } \\
5 \text { years }\end{array}$ & $1^{\text {st }}$ year & $\begin{array}{c}\text { Prospective } \\
\text { cohort. Parents } \\
\text { reports of illness }\end{array}$ & \begin{tabular}{|} 
Telephone ques- \\
tionnaires to \\
parents, every 2 \\
months for 2 \\
years
\end{tabular} & 498 & 1.1 & no & $0.4-3.1$ & $\begin{array}{c}1 \text { parent with a } \\
\text { history of } \\
\text { asthma or } \\
\text { allergy. No } \\
\text { association } \\
\text { with allergic } \\
\text { rhinitis }\end{array}$ \\
\hline $\begin{array}{l}\text { Jedrychowski } \\
\text { et al. } 2006 \text { [28] }\end{array}$ & Krakow, age 1 year & Pregnancy & $\begin{array}{l}\text { Prospective } \\
\text { cohort }\end{array}$ & $\begin{array}{l}\text { Questionnaires } \\
\text { to mothers every } \\
3 \text { months }\end{array}$ & 102 & 2.30 & No & $0.91-5.80$ & \\
\hline $\begin{array}{l}\text { McKeever et al. } \\
2002[37]\end{array}$ & $\begin{array}{l}\text { Children in the } \\
\text { English midlands, } \\
\text { age } 11 \text { years }\end{array}$ & Pregnancy & $\begin{array}{l}\text { Retrospective } \\
\text { cohort }\end{array}$ & $\begin{array}{c}\text { Database of GP } \\
\text { records }\end{array}$ & 24690 & (aHR) 1.19 & Yes & $1.09-1.31$ & $\begin{array}{l}\text { Risk increases } \\
\text { with more } \\
\text { courses. Simi- } \\
\text { lar association } \\
\text { with hayfever }\end{array}$ \\
\hline $\begin{array}{l}\text { Sariachvili et al. } \\
\quad 2007 \text { [44] }\end{array}$ & $\begin{array}{l}\text { Belgium. Infants } \\
\text { age } 1\end{array}$ & Pregnancy & $\begin{array}{l}\text { Prospective } \\
\text { cohort. Parents' } \\
\text { reports of ec- } \\
\text { zema }\end{array}$ & $\begin{array}{l}\text { Retrospective } \\
\text { reports of moth- } \\
\text { ers at } 5 \text { months' } \\
\text { gestation \& } 3 \\
\text { months of life }\end{array}$ & 976 & 1.8 & Yes & $1.2-2.7$ & \\
\hline
\end{tabular}


In the main, these are retrospective studies, relying on questionnaires administered to parents, asking for recall of administration of antibiotics up to 6 to 10 years previously. Information collected from participants is vulnerable to recall bias and, if collected more than 2 weeks after the event, forgetfulness [48], which concurs with our experience that many parents are unable to recall accurately the names, doses and usage of antibiotics over a 6 week period. Most retrospective questionnaire data collection in this area has used the ISAAC questionnaire. A retest of this questionnaire by 347 parents within 12 months gave a kappa value of 0.63 (95\% CI 0.57-0.69) for reports of antibiotic usage in the first 3 years of life, indicating incomplete agreement between parents' initial response and the re-test [40].

More work has been done on asthma, and the findings are less equivocal (Table 2). A meta-analysis of 8 studies indicated that use of any antibiotics in the first year of life was significantly associated with childhood asthma. The association was stronger in retrospective than prospective cohorts (OR 2.82 (2.07-3.85) versus OR 1.12 (0.88-1.42)), highlighting the need for further prospective work [49]. Also, the largest study suggested a dose/response relationship: antibiotic administration in the first year of life increased the risk of GP diagnosis of asthma before age 11, depending on the number of courses prescribed: HR $1.26(1.13-1.40)$ for one course, and HR 1.99 (1.72-2.31) for four or more courses [37]. Most studies support these findings [34, 38-42, 50, 51]. However, the association is refuted by a body of research, mainly that relying on parental report of antibiotic use [52, 53], but also two record reviews [45, 54], and a case-control study found an association for use in the first 3 years, but not the first year [55]. Although children living on farms in Eastern Europe are relatively immune from allergic disorders, asthma is more common amongst children on farms in the American mid-West where antibiotics are added to animal feed [56].

Some studies which linked antibiotics to asthma or eczema found no association between antibiotics and atopy (assessed by skin prick tests or measurement of IgE antibodies in venous blood) [34, 40, 41, 50, 51] (Table 3).

Allergic disorders and atopy tend to run in families, but only smaller studies have focused on families at high risk of allergic disorders $(n=1460,448,937$, total 2845) [39, 52, 53], and the largest of these was retrospective. The impact of antibiotics may be limited to certain subgroups, for example, homes with $<2$ pets, infants breastfed $>4$ months [57], or a family history of allergy (OR for eczema $1.695 \% \mathrm{CI} 1.0-2.6$ ) [41]. There are suggestions that type of antibiotic is important, with broad-spectrum antibiotics having a stronger association $[37,38]$.

\section{ANTIBIOTICS AND PROBIOTICS}

The bacteria which colonise the sterile gastrointestinal tract of newborn infants include lactic acid producing bacteria, enterobacteria, streptococci and staphylococci [58]. Where lactic acid producing bacteria are relatively deficient in the gut microflora, the neonatal immune system develops suboptimally, leaving the infant susceptible to allergic disorders [59].
Probiotic food supplements contain lactic acid producing bacteria and are known to affect the neonatal gut flora. It is suggested that this induces the maturation of Th1 cells, which inhibit the development of the signs and symptoms of allergy $[60,61]$. The potential of prophylactic probiotics to prevent allergic disorders $[60,62]$ is supported by a metaanalysis of 5 clinical trials with atopic dermatitis/ eczema as the primary outcome (relative risk $0.61(0.49-0.74$ in a fixed effects model, $n=1406$ ) [63]. Clinical trials of infant formula feeds containing probiotic organisms are underway $[64,65]$. However, there are concerns that any benefits probiotics confer could be negated by antibiotics, which disrupt the gut flora $[39,66,67]$.

\section{EVIDENCE FOR ADVERSE EFFECTS}

There is no single hierarchy of evidence or a single 'gold standard' research method for the identification of the adverse effects of treatment [68]. Even the best-funded randomised controlled trials are rarely powered to detect adverse effects $[69,70]$, and the best-conducted trials may be confounded or obfuscated by cross-over [71].

To date, ethical and practical considerations, not least the time between antibiotic administration and the onset of allergic disorders, have precluded investigation of this adverse drug reaction by clinical trials. Causal relationships between medication and adverse events cannot always be formally tested by experimental research, and may retain an element of subjective interpretation $[68,72,73]$. Therefore, the doseresponse relationship remains pivotal in identifying adverse drug reactions [74] and establishing causality [19, 75]. Although the putative association between antibiotics and allergic disorders has been explored by a variety of nonexperimental methods (Tables 1-3), none of these studies have recorded doses prescribed or obtained detailed information on the balance of the immune system and its cytokines, leaving some of the Bradford Hill [19] criteria unfulfilled.

Antibiotic administration is unlikely to be the only cause of allergic disorders. There are several possible explanations for the increased incidence in allergic disorders that coincided with the introduction of antibiotics: genetic predisposition, infant feeding, urban living and other environmental factors are likely to be involved. Associations uncovered in non-experimental observational research do not allow attribution of causation: children vulnerable to allergic disorders may also be in greater need of antibiotics, and children with asthma are prescribed more antibiotics than their contemporaries [76]. Although children wheezing at age 8 were prescribed more antibiotics, the association almost disappeared when only antibiotics for non-respiratory infections were considered (OR 1.05 CI 1.00-1.10) [53]. In contrast, other work indicated that the association remained when antibiotics for lower respiratory tract infections are excluded [38].

Asthma is associated with repeated upper respiratory tract infections in childhood [77]. While some studies indicate that children with atopy suffer more viral infections [38], the largest UK cohort found no association between infections and allergic disorders [37], and low numbers of respiratory tract infections, allergies and antibiotic prescriptions characterise 
Table 2. Antibiotic Exposure and Risk of Asthma

\begin{tabular}{|c|c|c|c|c|c|c|c|c|c|}
\hline Ref. & Population & $\begin{array}{c}\text { Time of } \\
\text { Antibiotic } \\
\text { Prescription } \\
\text { (s) }\end{array}$ & Method & $\begin{array}{l}\text { Antibiotic Use As- } \\
\text { sessed by }\end{array}$ & $\begin{array}{l}\text { Number } \\
\text { in Study }\end{array}$ & $\begin{array}{l}\text { Findings } \\
/ \text { OR }\end{array}$ & $\begin{array}{c}\text { Antibiotics } \\
\text { Associated } \\
\text { with Asthma } \\
\text { or Wheezing }\end{array}$ & $95 \% \mathrm{CI}$ & Comments \\
\hline $\begin{array}{l}\text { Marra et al. } \\
2006 \text { [49] }\end{array}$ & $\begin{array}{l}\text { Studies pub- } \\
\text { lished in Eng- } \\
\text { lish }\end{array}$ & $\begin{array}{c}1^{\text {st }} \text { year, at } \\
\text { least } 1 \text { course }\end{array}$ & $\begin{array}{l}\text { Meta-analysis, } 4 \\
\text { retrospective, plus } 4 \\
\text { prospective studies }\end{array}$ & Not specified & 27167 & 2.05 & yes & $1.41-2.99$ & $\begin{array}{c}\text { Association } \\
\text { stronger for } \\
\text { retrospective } \\
\text { studies }\end{array}$ \\
\hline $\begin{array}{l}\text { Ahn et al. } \\
2005[42]\end{array}$ & $\begin{array}{l}\text { Korean chil- } \\
\text { dren, aged } 7- \\
12\end{array}$ & $1^{\text {st }}$ year of life & Retrospective survey & $\begin{array}{l}\text { Retrospective } \\
\text { questionnaires to } \\
\text { parents }\end{array}$ & 26400 & 1.86 & Yes & $1.67-2.08$ & $\begin{array}{c}\text { Similar asso- } \\
\text { ciation with } \\
\text { wheeze in last } \\
12 \text { months }\end{array}$ \\
\hline $\mid \begin{array}{c}\text { McKeever } \\
\text { et al. } 2002[27]\end{array}$ & $\begin{array}{l}\text { Children in the } \\
\text { English mid- } \\
\text { lands, age } 11 \\
\text { years }\end{array}$ & $1^{\text {st }}$ year of life & Retrospective cohort. & $\begin{array}{c}\text { Database of GP re- } \\
\text { cords }\end{array}$ & 21129 & $\begin{array}{l}\text { (aHR) } \\
1.99\end{array}$ & yes & $1.72-2.31$ & \\
\hline$\left|\begin{array}{c}\text { Von Mutius } \\
\text { et al. } 1999[40]\end{array}\right|$ & $\begin{array}{l}\text { Dresden, chil- } \\
\text { dren 5-11 }\end{array}$ & $1^{\text {st }}$ year & $\begin{array}{c}\text { Survey, clinical } \\
\text { examination, venous } \\
\text { bloods for IgE }\end{array}$ & $\begin{array}{l}\text { Retrospective ques- } \\
\text { tionnaire to parents. }\end{array}$ & 12601 & 1.64 & yes & $1.26-2.13$ & \\
\hline $\begin{array}{c}\text { Floistrup et al. } \\
2006[34]\end{array}$ & $\begin{array}{c}\text { European } \\
\text { Steiner school } \\
\text { children and a } \\
\text { comparator } \\
\text { group, age 5- } \\
13\end{array}$ & $1^{\text {st }}$ year & $\begin{array}{l}\text { Survey of parents } \\
\text { IgE antibody } \\
\text { measurements }\end{array}$ & $\begin{array}{l}\text { Retrospective } \\
\text { questionnaires to } \\
\text { parents. }\end{array}$ & 6733 & 2.79 & Yes & $2.03-3.83$ & \\
\hline $\begin{array}{l}\text { Celedon et al. } \\
2004 \text { [45] }\end{array}$ & $\begin{array}{l}\text { Boston USA, } \\
\text { children age } 2 \text { - } \\
5,>4 \text { courses }\end{array}$ & $1^{\text {st }}$ year & Retrospective cohort & $\begin{array}{l}\text { Record review of } \\
\text { automated medical } \\
\text { record systems }\end{array}$ & 4408 & 0.9 & no & $0.6-1.3$ & \\
\hline $\begin{array}{l}\text { Cohet et al. } \\
2005 \text { [39] }\end{array}$ & $\begin{array}{l}\text { New Zealand } \\
\text { children age 6- } \\
7,1584 \text { with } \\
\text { previous noti- } \\
\text { fiable infection } \\
\text { plus a general } \\
\text { population } \\
\text { group }\end{array}$ & $1^{\text {st }}$ year & $\begin{array}{l}\text { Survey by mailed } \\
\text { questionnaire }\end{array}$ & $\begin{array}{l}\text { Retrospective } \\
\text { questionnaires to } \\
\text { parents. }\end{array}$ & 4123 & 2.10 & Yes & $1.79-2.48$ & $\begin{array}{l}\text { Asthma not } \\
\text { linked to } \\
\text { notifiable } \\
\text { infections }\end{array}$ \\
\hline$\left|\begin{array}{c}\text { Kummeling } \\
\text { et al. } 2007[47]\end{array}\right|$ & $\begin{array}{l}\text { Netherlands. } \\
\text { Children } \\
\text { wheezing in } 1^{\text {st }} \\
2 \text { years }\end{array}$ & $\begin{array}{c}1^{\text {st }} 6 \text { months, } \\
\text { including } \\
\text { administration } \\
\text { to breastfeed- } \\
\text { ing mothers }\end{array}$ & Prospective cohort & $\begin{array}{l}\text { Retrospective } \\
\text { questionnaires }\end{array}$ & 2764 & 2.32 & Yes & $1.55-3.48$ & \\
\hline $\begin{array}{c}\text { Farooqi and } \\
\text { Hopkin } 1998 \\
{[38]}\end{array}$ & $\begin{array}{c}\text { Children up to } \\
12 \text { in a family } \\
\text { doctor practice } \\
\text { in Oxfordshire, } \\
\text { UK }\end{array}$ & $1^{\text {st }} 2$ years & $\begin{array}{l}\text { Retrospective cohort } \\
\text { using. GP \& public } \\
\text { health records }\end{array}$ & GP records & 1934 & 3.19 & yes & $2.43-4.18$ & \\
\hline $\begin{array}{l}\text { Droste et al. } \\
2000[41]\end{array}$ & $\begin{array}{l}\text { Belgium, chil- } \\
\text { dren aged 7-8 }\end{array}$ & $1^{\text {st }}$ year & $\begin{array}{l}\text { Survey question- } \\
\text { naires to parents. } \\
\text { Skin prick tests }\end{array}$ & $\begin{array}{l}\text { Retrospective } \\
\text { questionnaires to } \\
\text { parents. }\end{array}$ & 1206 & 1.7 & $\begin{array}{l}\text { Confidence } \\
\text { interval in- } \\
\text { cludes } 1\end{array}$ & $1.0-3.1$ & \\
\hline $\begin{array}{c}\text { Illi et al. } 2001 \\
{[53]}\end{array}$ & $\begin{array}{l}\text { German chil- } \\
\text { dren aged } 7 \\
\text { years }\end{array}$ & $1^{\text {st }} 7$ years & $\begin{array}{l}\text { Prospective cohort. } \\
\text { Interviews of par- } \\
\text { ents, venous blood } \\
\text { samples for IgE } \\
\text { estimation, clinical } \\
\text { examination }\end{array}$ & $\begin{array}{l}\text { Parental report of } \\
\text { antibiotic use }\end{array}$ & 1120 & 1.08 & no & $0.59-1.99$ & $\begin{array}{l}\text { Antibiotics } \\
\text { for lower } \\
\text { respiratory } \\
\text { tract infec- } \\
\text { tions ex- } \\
\text { cluded }\end{array}$ \\
\hline $\begin{array}{l}\text { Cullinan et al. } \\
2004[50]\end{array}$ & $\begin{array}{c}\text { Asthma in } \\
\text { adults in Kent, } \\
\text { UK }\end{array}$ & $1^{\text {st }} 5$ years & $\begin{array}{c}\text { Retrospective cohort. } \\
\text { self-report of illness } \\
\text { as adult }\end{array}$ & $\begin{array}{l}\text { GP records of } \\
\text { prescriptions }\end{array}$ & 746 & 1.08 & yes & $1.03-1.13$ & \\
\hline
\end{tabular}




\begin{tabular}{|c|c|c|c|c|c|c|c|c|c|}
\hline Ref. & Population & $\begin{array}{c}\text { Time of } \\
\text { Antibiotic } \\
\text { Prescription } \\
\text { (s) }\end{array}$ & Method & $\begin{array}{l}\text { Antibiotic Use As- } \\
\text { sessed by }\end{array}$ & $\begin{array}{l}\text { Number } \\
\text { in Study }\end{array}$ & $\begin{array}{l}\text { Findings } \\
/ \text { OR }\end{array}$ & $\begin{array}{c}\text { Antibiotics } \\
\text { Associated } \\
\text { with Asthma } \\
\text { or Wheezing }\end{array}$ & $95 \%$ CI & Comments \\
\hline $\begin{array}{l}\text { Harris et al. } \\
2007 \text { [54] }\end{array}$ & $\begin{array}{l}\text { Children aged } \\
8 \text {, in Kent, UK }\end{array}$ & $1^{\text {st }} 5$ years & $\begin{array}{c}\text { Prospective cohort. } \\
\text { Annual retrospective } \\
\text { questionnaires to } \\
\text { parents }\end{array}$ & GP records & 523 & 1.07 & yes & $1.03-1.10$ & $\begin{array}{c}\text { Current } \\
\text { wheezing as } \\
\text { end point. } \\
\text { Association } \\
\text { reduces } \\
\text { when respi- } \\
\text { ratory infec- } \\
\text { tions are } \\
\text { discounted }\end{array}$ \\
\hline $\begin{array}{l}\text { Celedon et al. } \\
2002[52]\end{array}$ & $\begin{array}{l}\text { Boston USA, } \\
\text { children age } 5\end{array}$ & $1^{\text {st }}$ year & $\begin{array}{l}\text { Prospective cohort. } \\
\text { Parents' reports of } \\
\text { illness }\end{array}$ & $\begin{array}{l}\text { Retrospective ques- } \\
\text { tionnaires by tele- } \\
\text { phone to parents, } \\
\text { every } 2 \text { months for } 2 \\
\text { years }\end{array}$ & 498 & 0.9 & no & $0.4-1.8$ & \\
\hline $\begin{array}{c}\text { Wickens et al. } \\
1999 \text { [51] }\end{array}$ & $\begin{array}{c}\text { Children in } \\
\text { Steiner schools } \\
\text { in New Zea- } \\
\text { land }\end{array}$ & $1^{\text {st }}$ year & Survey of parents & $\begin{array}{l}\text { Retrospective } \\
\text { questionnaires to } \\
\text { parents }\end{array}$ & 456 & 2.74 & yes & $1.110-6.85$ & \\
\hline $\begin{array}{c}\text { Thomas et al. } \\
2006 \text { [55] }\end{array}$ & $\begin{array}{l}\text { Manchester, } \\
\text { UK, children } \\
\text { aged 3-5 }\end{array}$ & $1^{\text {st }}$ year & Case control. & $\begin{array}{c}\text { Medical records and } \\
\text { prospective parental } \\
\text { diaries }\end{array}$ & 72 & 1.32 & no & $0.99-1.78$ & $\begin{array}{c}\text { Association } \\
\text { found if first } \\
3 \text { years' use } \\
\text { was consid- } \\
\text { ered }\end{array}$ \\
\hline $\begin{array}{l}\text { McKeever } \\
\text { et al. } 2002[37]\end{array}$ & $\begin{array}{c}\text { Children in the } \\
\text { English mid- } \\
\text { lands, under } 11 \\
\text { years }\end{array}$ & $\begin{array}{c}\text { During preg- } \\
\text { nancy }>2 \\
\text { courses }\end{array}$ & $\begin{array}{l}\text { Retrospective co- } \\
\text { hort. }\end{array}$ & $\begin{array}{c}\text { Database of GP re- } \\
\text { cords }\end{array}$ & 24690 & $\begin{array}{l}\text { (aHR) } \\
1.12\end{array}$ & yes & $1.02-1.24$ & $\begin{array}{l}\text { Risk not } \\
\text { significant } \\
\text { with fewer } \\
\text { courses. }\end{array}$ \\
\hline $\begin{array}{c}\text { Jedrychowski } \\
\text { et al. } 2006[28]\end{array}$ & $\begin{array}{l}\text { Krakow chil- } \\
\text { dren age } 1 \\
\text { year, non- } \\
\text { smoking } \\
\text { mothers }\end{array}$ & $\begin{array}{l}\text { During } 2^{\text {nd }} \& \\
3^{\text {rd }} \text { trimesters } \\
\text { of pregnancy }\end{array}$ & Prospective cohort & $\begin{array}{c}\text { Retrospective } \\
\text { questionnaires to } \\
\text { mothers every } 3 \\
\text { months }\end{array}$ & 102 & 4.42 & yes & $1.05-18.8$ & $\begin{array}{c}\text { Similar } \\
\text { association } \\
\text { with allergic } \\
\text { rhinitis }\end{array}$ \\
\hline
\end{tabular}

Papers are ordered by sample size.

childhood in rural Poland [14]. The effect of antibiotics on allergic disorders is more marked for early exposure [37]. Crucial development of the immune system occurs in very early life [20]. Therefore, even large datasets without peripartum data, such as GP records, may fail to identify associations.

\section{DISCUSSION}

Allergic disorders remain a major public health problem, but their aetiology is largely unknown. Antibiotic prescribing has been extended to nurses and other health care professionals, devolving responsibilities from doctors to healthcare professionals who may have received a less detailed education and preparation in pharmacology and immunology, or may be more vulnerable to pharmaceutical industry promotions [78]. Antibiotics save lives and cure infections, but they can be over-prescribed $[79,80]$. When prescribed for sore throat, ear or upper respiratory tract infections, antibiotics reduce the risk of serious complications, but, in UK general practice, over 4,000 patients need to be treated to prevent one complication [81]. However, withholding therapy from severely ill patients may jeopardise the management of potentially serious or life-threatening infections [82, 83]. Delayed administration of antibiotics in patients with confirmed bacterial meningitis increases the risk of adverse out- comes [84]. For every 100 courses of antibiotics prescribed to treat chest infections in children, one case of pneumonia is prevented [81]. There are concerns that therapeutic Calvinism may be responsible for the rising incidence of rheumatic fever and renal damage secondary to streptococcal infections in children aged 4-15. Consequently, a more selective approach to antibiotic therapy for sore throats, using laboratory tests, is advocated [85]. This approach reduces antibiotic prescribing for children 3-17 with sore throats, but without reducing overall paediatric primary care antibiotic prescribing [18].

If antibiotic administration is to be rationalised, professionals and patients need full information of their risks and benefits or harms. Most antibiotic prescribing takes place in primary care, where there is considerable variation between practitioners [86]. Interventions to reduce antibiotic prescribing have been successful [87], which might indicate that scope for practice modification exists. Current guidelines and quality indicators for antibiotic prescribing focus on bacterial resistance, and offer no consensus [88, 89], reflecting tensions between the needs of individual patients and public health priorities [90]. However, due to the paucity of evidence, current guidelines take little account of allergic disorders. Those developing prescribing guidelines should not 
Table 3. Antibiotic Exposure and Risk of Atopy

\begin{tabular}{|c|c|c|c|c|c|c|c|c|c|}
\hline Ref. & Population & $\begin{array}{l}\text { Time of Anti- } \\
\text { biotic Pre- } \\
\text { scription (s) }\end{array}$ & Method & $\begin{array}{l}\text { Antibiotic Use } \\
\text { Assessed by: }\end{array}$ & $\begin{array}{l}\text { Number } \\
\text { in Study }\end{array}$ & $\begin{array}{l}\text { Findings/ } \\
\text { OR }\end{array}$ & $\begin{array}{l}\text { Antibiotics } \\
\text { Associated } \\
\text { with Atopy }\end{array}$ & $95 \% \mathrm{CI}$ & Comments \\
\hline $\begin{array}{l}\text { Von Mutius et } \\
\text { al. } 1999 \text { [40] }\end{array}$ & $\begin{array}{c}\text { Dresden, children } \\
\text { aged 5-11 }\end{array}$ & $\begin{array}{c}1^{\text {st }} \text { year }>5 \\
\text { courses }\end{array}$ & $\begin{array}{l}\text { Survey. Ques- } \\
\text { tionnaires to } \\
\text { parents, clinical } \\
\text { examination, } \\
\text { venous bloods } \\
\text { for IgE }\end{array}$ & \begin{tabular}{|} 
Antibiotic use \\
assessed by retro- \\
spective ques- \\
tionnaires
\end{tabular} & 5067 & 0.92 & no & $0.72-1.17$ & \\
\hline $\begin{array}{l}\text { Tamay et al. } \\
2007 \text { [43] }\end{array}$ & $\begin{array}{l}\text { Istanbul, children } \\
\text { aged } 6-12\end{array}$ & $1^{\text {st }}$ year & Survey & $\begin{array}{l}\text { Retrospective } \\
\text { questionnaires to } \\
\text { parents }\end{array}$ & $\begin{array}{l}2387, \\
95 \% \\
\text { response } \\
\text { rate }\end{array}$ & 1.26 & yes & $1.01-1.57$ & $\begin{array}{l}\text { Outcome was } \\
\text { allergic rhinitis, } \\
\text { used as marker } \\
\text { for atopy }\end{array}$ \\
\hline $\begin{array}{c}\text { Floistrup et al. } \\
2006[34]\end{array}$ & $\begin{array}{c}\text { Steiner school } \\
\text { children and a } \\
\text { comparator group, } \\
\text { age 5-13 }\end{array}$ & $1^{\text {st }}$ year & $\begin{array}{l}\text { Survey of par- } \\
\text { ents. Blood } \\
\text { samples for IgE } \\
\text { estimation }\end{array}$ & \begin{tabular}{|} 
Antibiotic use \\
assessed by retro- \\
spective ques- \\
tionnaires
\end{tabular} & 1856 & 1.15 & no & $0.84-1.58$ & \\
\hline $\begin{array}{c}\text { Kummeling et } \\
\text { al. } 2007 \text { [47] }\end{array}$ & $\begin{array}{l}\text { Netherlands. Chil- } \\
\text { dren up to } 2 \text { years }\end{array}$ & $\begin{array}{l}1^{\text {st }} 6 \text { months, } \\
\text { including } \\
\text { administration } \\
\text { to breastfeed- } \\
\text { ing mothers }\end{array}$ & $\begin{array}{l}\text { Prospective } \\
\text { cohort }\end{array}$ & \begin{tabular}{|} 
Antibiotic use \\
assessed by retro- \\
spective ques- \\
tionnaires
\end{tabular} & 815 & 1.32 & No & $0.86-2.02$ & \\
\hline $\begin{array}{l}\text { Cullinan et al. } \\
2004[50]\end{array}$ & $\begin{array}{l}\text { Atopy (positive } \\
\text { skin prick test) in } \\
\text { adults in Kent }\end{array}$ & $1^{\text {st }} 5$ years & $\begin{array}{l}\text { Retrospective } \\
\text { cohort, } \\
\text { self-report of } \\
\text { illness }\end{array}$ & $\begin{array}{l}\text { GP records of } \\
\text { prescriptions }\end{array}$ & 746 & OR 1.01 & no & $0.97-1.05$ & $\begin{array}{c}\text { No association } \\
\text { with hayfever, } \\
\text { but association } \\
\text { with asthma, } \\
\text { above }\end{array}$ \\
\hline $\begin{array}{l}\text { Droste et al. } \\
2000[41]\end{array}$ & $\begin{array}{l}\text { Belgium, children } \\
\text { aged 7-8 }\end{array}$ & $1^{\text {st }}$ year & $\begin{array}{l}\text { Survey ques- } \\
\text { tionnaires to } \\
\text { parents. Skin } \\
\text { prick tests }\end{array}$ & $\begin{array}{l}\text { Retrospective } \\
\text { questionnaires to } \\
\text { parents. }\end{array}$ & 675 & OR 1.1 & no & $0.7-1.7$ & \\
\hline $\begin{array}{l}\text { Harris et al. } \\
2007 \text { [54] }\end{array}$ & $\begin{array}{c}\text { Children aged 8, in } \\
\text { Kent, UK }\end{array}$ & $1^{\text {st }} 5$ years & $\begin{array}{c}\text { Prospective } \\
\text { cohort. Annual } \\
\text { retrospective } \\
\text { questionnaires to } \\
\text { parents }\end{array}$ & GP records & 490 & 1.00 & no & $0.97-1.03$ & $\begin{array}{l}\text { Atopy assessed } \\
\text { from notes }\end{array}$ \\
\hline $\begin{array}{c}\text { Johnson et al. } \\
2005 \text { [57] }\end{array}$ & $\begin{array}{l}\text { Detroit, USA, } \\
\text { children aged 6-7 }\end{array}$ & $1^{\text {st }} 6$ months & $\begin{array}{c}\text { Prospective } \\
\text { cohort Clinical } \\
\text { examination, } \\
\text { skin prick tests, } \\
\text { IgE from venous } \\
\text { blood }\end{array}$ & $\begin{array}{l}\text { All Medical } \\
\text { records. }\end{array}$ & 488 & 1.48 & no & $0.94-2.34$ & $\begin{array}{l}\text { associations in } \\
\text { subgroups }\end{array}$ \\
\hline
\end{tabular}

Papers are ordered by sample size.

aHR, adjusted hazard ratio; OR, odds ration; CI, confidence intervals; GP, general (medical) practitioner.

regard absence of evidence as equivalent to evidence of absence when considering the risk of adverse drug reactions.

Allergic disorders in childhood disproportionately afflict children from disadvantaged backgrounds [87], particularly the urban poor of the USA. The high incidence of allergic disorders amongst children of large families, living in overcrowded and rat or cockroach-infested homes reduces the plausibility of the 'hygiene hypothesis' [91]. Poorer preschool children are more likely to be prescribed antibiotics in primary care for viral infections [92], and at an earlier age [93]. Therefore, children from disadvantaged backgrounds will benefit most from modifications in GP prescribing.

The public health importance of this putative association indicates that this issue requires further exploration. It is important to capture and disseminate the impact of prescribing while the data is relatively contemporary. Previous studies are based on the prescribing patterns of the 1980s [38, 40,
$41,50,56]$ or earlier [49]. Changes in GP prescribing of antibiotics 1995-2000 [17] and epidemiological trends [15, 16] indicate that previous work may be obsolescent.

\section{IMPLICATIONS}

When caring for children who have received numerous courses of antibiotics and whose mothers received antibiotics in pregnancy, practitioners should be alert for the signs and symptoms of eczema and asthma and consider prompt referral.

Professionals, including nurses, making prescribing decisions, or planning follow-up patient monitoring and surveillance [94], need evidence on both the benefits and harms of medications. Evidence-based medicine is only valuable to the extent that the evidence base is complete [95]. Without prospective studies, the temporal link between respiratory tract infections, administration of antibiotics and allergic 
disorders and the appearance in the defect in Th1 maturation associated with allergic disorders [96] will remain unknown. If research funding, and research effort, is disproportionately devoted to assessing the benefits of prescribed medications, the evidence presented to practitioners may not be a true or valid reflection of reality.

Safe prescribing, and the prevention of adverse drug reactions, form an important part of the policy agenda [97, 98]. The importance of local and national guidelines in directing practice should not be underestimated [90, 99]. However, without further funding, prescribing guidelines will be unable to take account of the possibility that, when other risk factors are accounted for, there is both a dose-response relationship and a biologically plausible association between antibiotics prescribed and the incidence of allergic disorders in children.

\section{GLOSSARY}

- Antibodies. : Immunoglobulin proteins secreted by B lymphocytes. Antibody synthesis is induced by specific antigens, and they combine with these specific antigens usually to initiate pathogenic destruction. An antigen is any molecule, usually a protein or polysaccharide, that interact with an antibody. The term antigen is usually used in immunology to describe foreign material although antigens can be generated within the body e.g. A and B antigens on the surface of erythrocytes.

- Atopy. A genetic predisposition to immediate allergic response to common environmental antigens, such as pollen, house mites. Clinical manifestations include hayfever, asthma (some types), eczema or atopic dermatitis, food and drug allergies.

- Cytokines. Proteins released from cells of the immune system to communicate with and regulate other cells of the immune system.

- Histamine. This is released by basophils, mast cells and platelets. It causes local vascular dilation, an immediate increase in vascular permeability, swelling and itching. It is released on contact with stinging nettles and in some allergies. The problems caused by histamine are ameliorated by antihistamine creams or tablets.

- Th or helper $\mathbf{T}$ cells. Lymphocytes which direct other lymphocytes by releasing cytokines. The 2 main types are Th1 and Th2.

\section{REFERENCES}

[1] Holmes D, Murray S, Perron A, McCabe J. Nursing best-practice guidelines: reflecting on the obscene rise of the void. J Nurs Manag 2008; 16: 394-404.

[2] Rolfe G, Gardner L. Towards a geology of evidence-based practice. Int J Nurs Stud 2006; 43: 903-13.

[3] Holgate ST. The epidemic of allergy and asthma. Nature 1999; 402 (6760 Suppl): B2-4.

[4] Royal College of Physicians. Allergy: the unmet need. London: RCP, 2003.

[5] Austin J, Kaur B, Ross Anderson H, et al. Hay fever, eczema, and wheeze: a nationwide UK study (ISAAC, international study of asthma and allergies in childhood). Arch Dis Child 1999; 81: 22530 .
[6] Kurukulaaratchy R, Fenn M, Matthews S, Hasan Arshad S. The prevalence, characteristics of and early life risk factors for eczema in 10-year old children. Pediatr Allergy Immunol 2003; 14: 178-83.

[7] World Health Organisation. Fact Sheet no.307 Asthma. [Internet]. 2006; [cited 2008 March 21]. Available from: http://www.who. int/mediacentre/factsheets/fs307/en/index.html

[8] World Health Organisation. 2006 datasheets. [Internet]. [Cited 2008 March 21]. Available from: http://www.who.int/healthinfo/ gbdwhoregiondaly2000v3.xls

[9] Brown S, Reynolds NJ. Atopic \& non-atopic eczema. BMJ 2006; 332: $584-8$.

[10] International Study of Asthma and Allergies in Childhood (ISAAC) Steering Committee. Worldwide variation in prevalence of symptoms of asthma, allergic rhinoconjunctivitis, and atopic eczema: ISAAC. Lancet 1998; 351: 1225-32.

[11] Flohr C, Pascoe D, Williams H. Atopic dermatitis and the hygiene hypothesis: too clean to be true? Br J Dermatol 2005; 152: 206-16.

[12] Strachan DP. Hay fever, hygiene, and household size. BMJ 1989; 299: $125-60$

[13] Strachan DP. Family size, infection and atopy: the first decade of the "hygiene hypothesis". Thorax 2000; 55 (suppl 1): S2-10

[14] Majkowska-Wojciechowska B, Pełka J, Korzon L, et al. Prevalence of allergy, patterns of allergic sensitization and allergy risk factors in rural and urban children. Allergy 2007; 62:1044-50.

[15] Gupta R, Sheikh A, Strachan DP, Anderson HR. Time trends in allergic disorders in the UK. Thorax 2007; 62: 91-6.

[16] Grize L, Gassner M, Wuthrich B, et al. Swiss surveillance programme on childhood allergy and respiratory symptoms with respect to air pollution (SCARPOL) team. Trends in prevalence of asthma, allergic rhinitis and atopic dermatitis in 5-7-year old Swiss children from 1992 to 2001. Allergy 2006; 61: 556-62.

[17] Ashworth M, Charlton J, Latinovic R, Gulliford M. Age-related changes in consultations and antibiotic prescribing for acute respiratory infections, 1995-2000. Data from the UK General Practice Research Database. J Clin Pharm Ther 2006; 31: 461-7.

[18] Linder JA, Bates DW, Lee GM, Finkelstein JA. Antibiotic treatment of children with sore throat. JAMA 2005; 294: 2315-22.

[19] Hill AB. The environment and disease: association or causation. Proc R Soc Med 1965; 58: 295-300.

[20] Prescott SL, Macaubas C, Smallacombe T, Holt BJ, Sly PD, Holt PG. Development of allergen-specific T-cell memory in atopic and normal children. Lancet 1999; 353:196-200.

[21] Williams LK, Peterson EL, Ownby DR, Johnson CC. The relationship between early fever and allergic sensitization at age 6 to 7 years. J Allergy Clin Immunol 2004; 113: 291-6.

[22] Rook G, Brunet L. Microbes, immunoregulation, and the gut. Gut 2005; 54: 317-20.

[23] Yazdanbakhsh M, Kremsner P, van Ree R. Allergy, parasites, and the hygiene hypothesis. Science 2002; 296: 490-4.

[24] Guarner F, Malagelada JR. Gut flora in health and disease. Lancet 2003; 361: 512-9.

[25] Adlerberth I, Lindberg E, Aberg N, et al. Reduced enterobacterial and increased staphylococcal colonization of the infantile bowel: an effect of hygienic lifestyle? Pediatr Res 2006; 59: 96-101.

[26] Renz-Polster H, David MR, Buist AS, et al. Caesarean section delivery and the risk of allergic disorders in childhood. Clin Exp Allergy 2005; 35: 1466-72.

[27] McKeever TM, Lewis SA, Smith C, et al. Early exposure to infections and antibiotics and the incidence of allergic disease. A birth cohort study with the West Midlands General Practice Research Database. J Allergy Clin Immunol 2002; 109: 43-50.

[28] Jedrychowski W, Galas A, Whyatt R, Perera F. The prenatal use of antibiotics and the development of allergic disease in one year old infants. A preliminary study. Int J Occup Med Environ Health 2006; 19: 70-6.

[29] Russell AR, Murch SH. Could peripartum antibiotics have delayed health consequences for the infants? BJOG 2006; 113: 758-65.

[30] Penders J, Thijs C, Vink C, et al. Factors influencing the composition of the intestinal microbiota in early infancy. Pediatrics 2006; 118: 511-21.

[31] Westerbeek EA, van den Berg A, Lafeber HN, Knol J, Fetter WP, van Elburg RM. The intestinal bacterial randomized in preterm infants: a review of the literature. Clin Nutr 2006; 25: 361-8.

[32] Hall MA, Cole CB, Smith SL, Fuller R, Rolles CJ. Factors influencing the presence of faecal lactobacilli in early infancy. Arch Dis Child 1990; 65: 185-8. 
[33] Penders J, Thijs C, van den Brandt PA, et al. Gut microbiota composition and development of atopic manifestations in infancy: the KOALA birth cohort study. Gut 2006; 56: 661-7.

[34] Floistrup H, Swartz J, Bergstrom A, et al. Allergic disease and sensitization in Steiner school children. J Allergy Clin Immunol 2006; 117: 59-66.

[35] Hopkin JM. Early life receipt of antibiotics and atopic disorder. Clin Exp Allergy 1999; 29: 733-4.

[36] Hopkin JM. The rise of atopy and links to infection. Allergy 2002; 57 Suppl 72: 5-9.

[37] McKeever TM, Lewis SA, Smith C, Hubbard R. The importance of prenatal exposures on the development of allergic disease. A birth cohort study using the West Midlands General Practice Database. Am J Respir Crit Care Med 2002; 166: 827-32.

[38] Farooqi IS, Hopkin JM. Early childhood infection and atopic disorder. Thorax 1998; 53: 927-32.

[39] Cohet C, Cheung S, MacDonald C, et al. Infections, medication use and the prevalence of symptoms of asthma, rhinitis and eczema in childhood. J Epidemiol Community Health 2005; 58: 852.

[40] Von Mutius E, Illi S, Hirsch T, Leupold W, Keil U, Weiland SK. Frequency of infections and risk of asthma, atopy and airway hyperresponsiveness in children. Eur Respir J 1999; 14: 4-11.

[41] Droste JHJ, Wieringa MH, Weyler JJ, Nelen VJ, Vermeire PA, Van Bevers HP. Does the use of antibiotics in early childhood increase the risk of asthma and allergic disease? Clin Exp Allergy 2000; 30: 1547-53.

[42] Ahn KM, Lee MS, Hong SJ, et al. Fever, use of antibiotics, and acute gastroenteritis during infancy as risk factors for the development of asthma in Korean school-age children. J Asthma 2005; 42: 745-50.

[43] Tamay Z, Akcay A, Ones U, Guler N, Kilic G, Zencir M. Prevalence and risk factors for allergic rhinitis in primary school children. Int J Pediatr Otorhinolaryngol 2007; 71: 463-71.

[44] Sariachvili M, Droste J, Dom S, et al. Is breast feeding a risk factor for eczema during the first year of life? Pediatr Allergy Immunol 2007; 18: 410-7.

[45] Celedon JC, Fuhlbrigge A, Rifas-Shiman S, Weiss ST, Finkelstein JA. Antibiotic use in the first year of life and asthma in early childhood. Clin Exp Allergy 2004; 34: 1011-6.

[46] Purvis DJ, Thompson JM, Clark PM, et al. Risk factors for atopic dermatitis in New Zealand children at 3.5 years of age. Br J Dermatol 2005; 152: 742-9.

[47] Kummeling I, Stelma FF, Dagnelie PC, et al. Early life exposure to antibiotics and the subsequent development of eczema, wheeze, and allergic sensitization in the first 2 years of life: the KOALA Birth Cohort Study. Pediatrics 2007; 119: 225-31.

[48] Stewart W, Ricci J, Leotta C. Health-related lost productive time: recall interval and bias in LPT estimates. J Occup Environ Med 2004; 46: S12-22.

[49] Marra F, Lynd L, Combes M, et al. Does antibiotic exposure during infancy lead to development of asthma? A systematic review and meta-analysis. Chest 2006; 129: 610-8.

[50] Cullinan P, Harris J, Mills P, et al. Early prescriptions of antibiotics and the risk of allergic disease in adults: a cohort study. Thorax 2004; 59: 11-5.

[51] Wickens K, Pearce N, Crane J, Beasley R. Antibiotic use in early childhood and the development of asthma. Clin Exp Allergy 1999; 29: 766-71.

[52] Celedon JC, Litonjua AA, Ryan L, Weiss ST, Gold DR. Lack of association between antibiotic use in the first year of life and asthma, allergic rhinitis or eczema at age 5 years. Am J Respir Crit Care Med 2002; 166: 72-5.

[53] Illi A, Von Mutius E, Lau S, et al. MAS Group. Early childhood infectious diseases and the development of asthma up to school age: a birth cohort study. BMJ 2001; 322: 390-5.

[54] Harris JM, Mills P, White C, Moffat S, Newman Taylor AJ, Cullinan $P$. Recorded infections and antibiotics in early life: associations with allergy in UK children and their parents. Thorax 2007; 62: 631-7.

[55] Thomas M, Custovici A, Woodcock A, Morris J, Simpson A, Murray CS. Atopic wheezing and early life antibiotic exposure: a nested case-control study. Pediatr Allergy Immunol 2006; 17: 184188 .

[56] Merchant JA, Naleway AL, Svendsen ER, et al. Asthma and farm exposures in a cohort of rural Iowa children. Environ Health Perspect 2005; 113: 350-6.
[57] Johnson CC, Ownby DR, Allford SH, et al. Antibiotic exposure in early infancy and risk for childhood atopy. J Allergy Clin Immunol 2005; 115: 1218-24

[58] Kuhn J, Jullius K. Colonisation and persistence of E. coli phenotypes in intestine of children aged 0-18 months. Infect Immun 1986; 14: 7-12

[59] Sepp E, Julge K. Intestinal Microflora of Estonian and Swedish infants. Acta Paediatr 1997: 86: 956-61.

[60] Kalliomaki, M, Kirjavainen P, Eerola E, Kero P, Salminen S, Isolauri E. Distinct patterns of neonatal gut microflora in infants in whom atopy was and was not developing. J Allergy Clin Immunol 2001; 107: 129-34

[61] Kalliomaki M, Isolauri E. Probiotics and down-regulation of the allergic response. Immunol Allergy Clin North Am 2004; 24: 73952.

[62] Kukkonen K, Savilahti E, Haahtela T, et al. Probiotics and prebiotic galacto-oligosaccharides in the prevention of allergic diseases. A randomized, double-blind, placebo controlled trial. J Allergy Clin Immunol 2007; 119: 192-8.

[63] Lee J, Seto D, Bielory L. Meta-analysis of clinical trials of probiotics for prevention and treatment of pediatric atopic dermatitis. J Allergy Clin Immunol 2008; 121: 116-21.

[64] Saavedra JM, Abi-Hanna A, Moore N, Yolken RH. Long-term consumption of infant formulas containing live probiotic bacteria: tolerance and safety. Am J Clin Nutr 2004; 79: 261-7.

[65] Puccio G, Cajozzo C, Meli F, Rochat F, Grathwohl D, Steenhout P. Clinical evaluation of a new starter formula for infants containing live Bifidobacterium longum BL999 and prebiotics. Nutrition 2007; 23: $1-8$.

[66] Noverr MC, Huffnagle GB. The 'microflora hypothesis' of allergic diseases. Clin Exp Allergy 2005; 35: 1511-20.

[67] Viljanen M, Savilahti E, Haahtela T, Juntunen-Backmane K. Probiotics in the treatment of atopic eczema/dermatitis syndrome in infants: a double-blind placebo-controlled trial. Allergy 2005; 60: 494-500.

[68] Jordan S. Adverse drug reactions: reducing the burden of treatment Nurs Stand 2007; 21: 35-41.

[69] Eypasch E, Lefering R, Kum CK, Troidl H. Probability of adverse events that have not yet occurred: a statistical reminder. BMJ 1995; 311: 619-20

[70] Ferner RE. Newly licensed drugs. BMJ 1996; 313: 1157-8.

[71] Henderson JJ, Dickinson JE, Evans SF, McDonald SJ, Paech MJ Impact of intrapartum epidural analgesia on breast-feeding duration. Aust N Z J Obstet Gynaecol 2003; 43: 372-7.

[72] Auriche M, Loupi E. Does proof of casualty ever exist in pharmacolvigilance? Drug Saf 1993; 9: 230-5.

[73] Spencer L, Ritchie J, Lewis J, Dillon L. Quality in qualitative evaluation. London: Government Chief Social Researcher's Office, Cabinet Office; 2003.

[74] Aronson J, Ferner R. Joining the DoTS: new approach to classifying adverse drug reactions. BMJ 2003; 327: 122-5.

[75] Jordan S, Emery S, Bradshaw C, Watkins A, Friswell W. The impact of intrapartum analgesia on infant feeding. BJOG 2005; 112 : 927-34.

[76] Stallworth LE, Fick DM, Ownby DR, Waller JL. Antibiotic use in children who have asthma: results of retrospective database analysis. J Manag Care Pharm 2005; 11: 657-62.

[77] Hak E, Rovers MM, Sachs AP, Stalman WA, Verheij TJ. Is asthma in 2-12 year-old children associated with physician-attended recurrent upper respiratory tract infections? Eur J Epidemiol 2003; 18: 899-902.

[78] Jutel A, Menkes D. Soft targets: nurses and the pharmaceutical industry. PloS Medicine [serial on the Internet]. 2008 February 5; [cited 2008 March 21]; 5(2) e5: [about 23 screens]. Available from: www.plosmedicine.org

[79] Gilberg K, Laouri M, Wade S, Isonaka S. Analysis of medication use patterns: apparent overuse of antibiotics and underuse of prescription drugs for asthma, depression, and CHF. J Manag Care Pharm 2003; 9: 232-7.

[80] Sanz EJ, Hernández MA, Ratchina S, et al. Prescribers' indications for drugs in childhood: a survey of five European countries (Spain, France, Bulgaria, Slovakia and Russia). Acta Paediatr 2005; 94 1784-90.

[81] Petersen I, Johnson AM, Islam A, Duckworth G, Livermore DM, Hayward AC. Protective effect of antibiotics against serious complications of common respiratory tract infections: retrospective co- 
hort study with the UK General Practice Research Database. BMJ 2007; 335: 982 .

[82] Berkley JA, Maitland K, Mwangi I, et al. Use of clinical syndromes to target antibiotic prescribing in seriously ill children in malaria endemic area: observational study. BMJ 2005; 330: 995.

[83] Chambers H. In: Brunton L, Lazo J, Parker K, Eds. Goodman \& Gilman's: the pharmacological basis of therapeutics. $11^{\text {th }}$ ed. New York, McGraw-Hill 2006; 1095-111.

[84] Aronin SI, Peduzzi P, Quagliarello VJ. Community-acquired bacterial meningitis: risk stratification for adverse clinical outcome and effect of antibiotic timing. Ann Intern Med 1998; 129: 862-9.

[85] Steer AC, Danchin MH, Carapetis JR. Group A streptococcal infections in children. J Paediatr Child Health 2007; 43: 203-13.

[86] Akkerman AE, Kuyvenhoven MM, Van der Wouden J, Verheij TJM. Prescribing antibiotics for respiratory tract infections by GPS: management and prescriber characteristics. Br J Gen Pract 2005; 55: 114-8

[87] Dollman WB, LeBlanc VT, Stevens L, O'Connor PJ, Turnidge JD. A community-based intervention to reduce antibiotic use for upper respiratory tract infections in regional South Australia. Med J Aust 2005; 182: 617-20.

[88] Matthys J, De Meyere M, van Driel ML, De Sutter A. Differences among international pharyngitis guidelines: not just academic. Ann Fam Med 2007; 5: 436-43.

[89] Coenen S, Ferech M, Haaijer-Ruskamp FM, et al. ESAC Project Group. European Surveillance of Antimicrobial Consumption (ESAC): quality indicators for outpatient antibiotic use in Europe. Qual Saf Health Care 2007; 16: 440-5.

[90] Cosby JL, Francis N, Butler CC. The role of evidence in the decline of antibiotic use for common respiratory infections in primary care. Lancet Infect Dis 2007; 7: 749-56.
[91] Platts-Mills TA, Carter MC, Heymann PW. Specific and nonspecific obstructive lung disease in childhood: causes of changes in the prevalence of asthma. Environ Health Perspect 2000; 108 Suppl 4: 725-31.

[92] Gupta R, Sheikh A, Strachan DP, Anderson HR. Burden of allergic disease in the UK: secondary analyses of national databases. Clin Exp Allergy 2004; 34: 520-6.

[93] Kozyrskyj AL, Dahl ME, Chateau DG, Mazowita GB, Klassen TP, Law BJ. Evidence-based prescribing of antibiotics for children: role of socioeconomic status and physician characteristics. CMAJ 2004; 171: 139-45.

[94] Jordan S. The prescription drug guide for nurses. Maidenhead: Open University Press, McGraw-Hill; 2008.

[95] Turner E, Matthews A, Linardatos E, Tell R, Rosenthal R. Selective publication of antidepressant trials and its influence on apparent efficacy. New Engl J Med 2008; 358: 252-60.

[96] Wjst $\mathrm{M}$. Is the increase in allergic asthma associated with an inborn Th1 maturation or with an environmental Th1 trigger defect? Allergy 2004; 59: 148-50.

[97] Healthcare Commission. State of healthcare 2006. [Internet]. 2006; [cited 2008 March 21]. Available from: http://www.healthcareco mmission.org.uk/db/_documents/State_of_Healthcare_2006 English tagged 200701023846.pdf

[98] Welsh Assembly Government (WAG). Designed for life: creating world class health and social care for Wales in the $21^{\text {st }}$ Century. Cardiff: Welsh Assembly Government; 2005.

[99] Rolfe G, Segrott J, Jordan S. Tensions and contradictions in nurses' perspectives of evidence based practice. J Nurs Manag 2008; 16: $441-52$.

(C) Jordan et al.; Licensee Bentham Open.

This is an open access article distributed under the terms of the Creative Commons Attribution License (http: //creativecommons.org/licenses/by/2.5/), which permits unrestrictive use, distribution, and reproduction in any medium, provided the original work is properly cited. 